\title{
PHOSPHATE PROSPECTION IN THE ALKALINE PROVINCE OF ALTO DO PARANAÍBA, BRAZIL, BASED ON AIRBORNE GEOPHYSICAL DATA
}

\author{
Leila Márcia Mendes Carvalho ${ }^{1}$, Augusto César Bittencourt Pires ${ }^{1}$ and Roberta Mary Vidotti ${ }^{2}$
}

\begin{abstract}
This paper aims to identify, differentiate and characterize geophysically phosphate deposits in metasedimentary rocks and carbonatite for standard geophysical set to facilitate the exploration of this mineral, using processing techniques and integration aerial magnetometric and aerial gamma spectrometric data. The area is located in the Upper Paranaíba Alkaline Province (PAAP), Minas Gerais State, Brazil, characterized by Cretaceous alkaline rocks that intrude Neoproterozoic rocks of the Brasília Belt. They include kimberlites, olivine lamproites madupíticos, kamafugites, alkaline-carbonatite complexes and dykes of phlogopite picrito, hosting carbonatite complex. These phosphate deposits are found in the region metasediments. Phosphates in metasedimentary rocks show high levels of uranium and reason $\mathrm{eU} / \mathrm{eTh}$ and similar smaller bodies of these deposits have been identified through the RGB and CMY. Phosphates in carbonatites occur in the outer edges of the body and high concentrations of eTh and eU, with different internal standards and influenced by tropical weathering. The main lineaments are NW-SE, E-W and NE-SW, where NE-SW is cut by NW-SE representing first event in the area, while E-W is assigned to subsequent event or reactivated during this phase. The geological and geophysical correlation shows that magnetic fields have a direct correspondence with the geology of carbonatites, because present a high concentration of magnetic minerals.
\end{abstract}

Keywords: aerial gamma spectrometry, aerial magnetometry, mineral prospecting, phosphate.

RESUMO. 0 presente trabalho objetiva identificar, diferenciar e caracterizar geofisicamente depósitos de fosfato em rochas metassedimentares e carbonatíticas para definir um padrão geofísico que facilite a prospecção deste mineral, utilizando técnicas de processamento e integração de dados aeromagnetométrico e aerogamaespectrométrico. A área situa-se na Província Alcalina do Alto do Paranaíba (PAAP), Minas Gerais, caracterizada por rochas alcalinas cretáceas, que intrudem rochas neoproterozóicas da Faixa Brasília. Elas incluem kimberlitos, olivina lamproitos madupíticos, kamafugitos, complexos alcalino-carbonatíticos e diques de flogopita picrito, que alojam complexos carbonatíticos. Nesta região encontram-se depósitos de fosfatos em rochas metassedimentares. Os fosfatos em rochas metassedimentares mostram teores elevados de urânio e da razão eU/eTh; além disso, corpos menores similares a esses depósitos foram identificados através do RGB e CMY. Os fosfatos em carbonatitos ocorrem nas bordas externas do corpo e concentrações elevadas de eTh e eU, além de padrões internos diferenciados e influenciados pelo intemperismo tropical. Os principais lineamentos são NW-SE, E-W e NE-SW, onde NE-SW é cortada por NW-SE representando primeiro evento na área, enquanto E-W é atribuído a evento posterior ou reativado nessa fase. A correlação geológico-geofísica mostra que os domínios magnéticos têm uma correspondência direta com a geologia dos carbonatitos, devido a estes apresentarem uma concentração elevada de minerais magnéticos.

Palavras-chave: gamaespectrometria aérea, magnetometria aérea, prospecção mineral, fosfato.

\footnotetext{
1Universidade de Brasília, Instituto de Geociências, Asa Norte, 70910-900 Brasília, DF, Brazil. Phone: +55(61) 8678-1531; Fax: +55(61) 3340-4759 - E-mails: geocriador@gmail.com/Immc@unb.br; acbpires@unb.br

2 Universidade de Brasília, Instituto de Geociências, Campus Universitário Darcy Ribeiro, Caixa Postal 04465, 70919-970 Brasília, DF, Brazil. Phone: +55(61)3107-6985; Fax: +55(61) 3340-4759 - E-mail: roberta@unb.br
} 


\section{INTRODUCTION}

Phosphate, Sulfur and Potassium make up the group called Agrominerals, these minerals are the main raw material used in the NPK chemical fertilizers and are considered basic inputs in agriculture (Fernandes et al., 2010). Globally, the phosphate rock is the only viable source of phosphorus while the sedimentary and igneous origin deposits are the most important from the economic viewpoint, of less economic importance, the biogenetic deposits display organic nitrogen concentrations that result from bird feces. Deposits of sedimentary origins constitute about $85 \%$ of the world supply, while the igneous and biogenetic deposits constitute about $15 \%$ and $1 \%$, respectively (Fernandes et al., 2010). About $80 \%$ of Brazilian natural phosphate deposits, found especially as $\mathrm{P}_{2} \mathrm{O}_{5}$, are of igneous origin with marked presence of carbonatite rocks and micaceous minerals (Fernandes et al., 2010).

Phosphate fertilizers display relatively high solubility in water while the predominantly tropical climate in Brazil favor their rapid dissolution, making $P$ highly available to the environment, following the model adopted in temperate countries (Sant'anna et al., 1999). The resulting great phosphorus loss requires constant addition of $\mathrm{P}$ to the soil to ensure adequate supply to crops, therefore, this study aims to identify, differentiate and characterize geophysically the phosphate deposits present in carbonatite rocks and metasedimentary units in the southwest region of Minas Gerais and the proposed geophysical patterns aim to facilitate the exploration of this mineral. The airborne geophysical, magnetometric and gamma spectrometric data were processed and integrated in order to generate products that allow better identification of geophysical patterns associated with the two types of phosphate occurrences in this region. The study site, located in the southwestern region of Minas Gerais, is covered by Area 7 and Area 1 projects of the airborne geophysical survey of Minas Gerais and encompasses five counties, Araxá, Lagamar, Ibiá, Tapira and Campos Altos (Fig. 1).

\section{METHODS AND DATA PROCESSING}

The methods applied, airborne magnetometric and gamma spectrometric, sought to establish comparative parameters, from the geophysical and geological points of view, between the areas already producing phosphate, in the Alkaline Province of Alto do Paranaíba, Minas Gerais, and nearby areas. The work area includes the project areas 7 (Patos de Minas-Araxá-Divinópolis) and 1 (Unaí-Paracatu-Vazante-Coromandel) of the Airborne Geophysical Survey Program of Minas Gerais (Fig. 1). Area 7 consists of $185.3 \mathrm{~km}^{2}$ covered with magnetometric and gamma ray spectrometric high resolution data, with flight and control lines spaced $0.4 \mathrm{~km}$ and $8.0 \mathrm{~km}$, towards N-S and E-W, respectively, at $100 \mathrm{~m}$ flying height. Area 1 was divided into North and South, the southern portion, used in this work, covered an area of $8.5 \mathrm{~km}^{2}$ with N3OW production and N60E control lines and the spacing between production and control lines was $0.25 \mathrm{~km}$ and $2.5 \mathrm{~km}$, respectively, at $100 \mathrm{~m}$ flying height. The two data sets were processed separately and then integrated and data integration was supported by the statistical analysis of the data at the junction of the two surveys and the tools available in the software used for processing.

The airborne magnetometric and gamma spectrometric data were treated using the Oasis Montaj ${ }^{\mathrm{TM}} 7.0$ software, data inconsistencies were removed, subsequently, the data were interpolated in regular grid using the bidirectional splines method for magnetometry and minimum curvature for gamma ray spectrometric, in a $100 \mathrm{~m} \times 100 \mathrm{~m}$ square cell. The process generated images that were used to facilitate the qualitative interpretation of geophysical units and structures and all interpretations and integrations used the Geographic Information System (GIS) to facilitate the analysis and presentation of final results.

\section{PHOSPHATE DEPOSITS IN BRAZIL}

Currently, Brazil is the largest producer of phosphate in South America and among the top 10 producers in the world (DNPM, 2008), this prominent position is mainly due to production originating from the magmatic deposits associated with alkalinecarbonatite complexes, there are currently three known natural sources of phosphate.

The igneous deposits derived from alkaline rocks (carbonatite) that occur in the regions of Catalão, Goiás, Araxá and Patrocínio, in Minas Gerais; Jacupiranga, in São Paulo; and Anitápolis, in Santa Catarina, among others. These sources found in the alkaline-carbonatite complexes, also contain the kimberlite provinces, and occur in arched and fault areas on the edges of the Paraná, Parnaíba (Almeida, 1976) and Amazon basins. The Brazilian alkaline provinces are controlled by at least three major structural lineaments; the most important has the general direction given by the $125^{\circ}$ azimuth, $125^{\circ} \mathrm{AZ}$ (Biondi, 2003). This lineament, known as Alto do Paranaíba Lineament in the Triângulo Mineiro and southeast Goiás, borders on the northeast, the Paraná Basin and on the southeastern part, the San Francisco craton. This relatively narrow band, which consists of metamorphite of the Brasilia Belt, comprises the most economically important alkaline-carbonatite complexes and the largest kimberlitelamproite province known in the country, and phosphate metasedimentary units, as well (Fig. 1). The Alkaline Province of Alto 


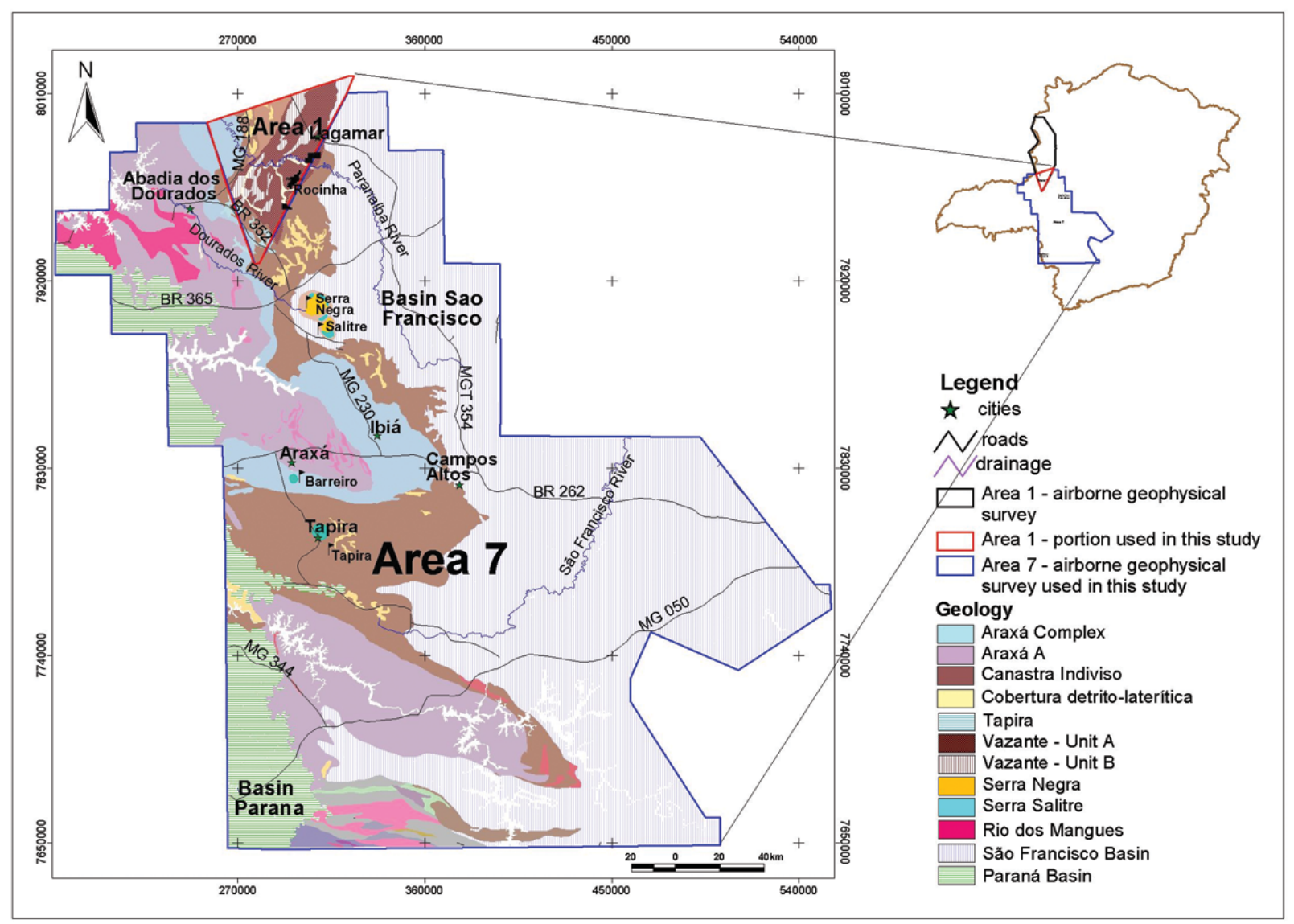

Figure 1 - Geological map of Alto do Paranaíba Province (Bizzi et al., 2003) showing the project areas 1 and 7 of the Airborne Geophysical Survey Program of Minas Gerais. The northern region concentrates the phosphate deposits in metasedimentary rocks, whereas the carbonatite rocks are in the central up to the east/southeast end region.

do Paranaíba includes occurrences of kimberlite, lamproite, kamafugite and carbonatite. Generally, magnetic surveys in the region show that these bodies have characteristic expression represented by circular or dipolar anomalies.

Marine sediment - certainly, the largest source of phosphate found on every continent (except Antarctica), from the Archean to the Recent. It accounts for over $80 \%$ of the production of phosphate rock in the world, and thus has enormous economic importance.

\section{GEOLOGICAL CONTEXT}

The site is located on the southwestern edge of the Craton. Its rocks belong to the Brasilia Fold Belt, which forms the basement of the Phanerozoic units of the São Francisco and Paraná basins, this region has a large number of alkaline ultramafic intrusions inserted in the Alkaline Province of Alto do Paranaíba (APAP) (Fig. 1). The Brasilia Fold Belt has generally NW-SE direction, with increasing metamorphic grade from east to west, with incipient facies until granulite and the varied intensity of this metamorphism allowed dividing the metamorphic zones into Cratonic, External and Internal (Fuck, 1994). On the other hand, the Mega-inflexion at parallel $16^{\circ} \mathrm{S}$ called Syntax or Mega-inflection of the Pirineus, identified in the region of Pirenópolis and Corumbá, Goiás, by Costa et al. (1970), also allows the subdivision of the range into North and South segments (Fonseca \& Dardenne, 1996). This is justified by the difference in tectonic evolution, to the north and south of this structure called Syntax or Mega-inflection of the Pirineus and the main feature of the northern segment is the preservation of the unique features of their units and their contact relationships, is formed by Araí, Paranoá, Serra da Mesa groups, in addition to the volcanic-sedimentary sequences of Juscelândia, Indaianópolis and Palmeirópolis (Dardenne, 2000).

The great structural and stratigraphic complexity of the southern segment prevents, sometimes, stacking its units and 
defining sedimentary environments, the segment is composed by the Vazante and Canastra groups, Ibiá Formation, and Araxá Group. This work emphasizes the south segment, where the study area is inserted.

The Vazante Group occupies an elongated N-S strip, approximately $250 \mathrm{~km}$ long, located in northwestern Minas Gerais, between the cities of Unaí and Coromandel (Dardenne, 1978) and its geology has been defined as interbedded carbonate and pelitic units. The carbonate units are characterized by bioherms, dolomitic breccias and limestone, the pelitic units are mainly slates and phyllites, intensely folded, with kinks and chevrons, two folding directions are printed in this group and their interference generates a pattern identified as the dome-basin type (Dardenne, 1978). This group was divided, from bottom to top, in seven formations: Santo Antonio do Bonito, Rocinha, Lagamar, Serra do Garrote, Serra do Poço Verde, Morro do Calcáreo and Lapa (Dardenne et al., 1997) and important mineralization of $\mathrm{Pb}$ and Zn associated with the carbonates of Morro do Calcáreo Formation and $\mathrm{Zn}$ in Serra do Poço Verde Formation are present, the phosphate deposits of Rocinha and Lagamar are located in the basal portion of this group (Sánchez et al., 2007).

In the Lagamar region, this formation consists of three units:

(I) the lower psamo-pelitic sequence, called Rocinha member, is the basis of the formation and consists of sandysilty-clayey meta-rhythmites, housing the Rocinha and Lagamar deposits;

(II) the sequence called Arrependido branch, composed of medium clay-carbonate conglomerates, is followed by a predominantly clayey sequence, interspersed with large carbonate lenses, included in the Lagamar branch;

(III) upper clay sequence composed mainly of laminated slates, named Serra do Garrote branch.

The Canasta Group, identified as part of a passive margin basin open at the end of the Mesoproterozoic, predominates south of Brasilia and presents conspicuous contact relationships with the Araxá Group. Its rocks outcrop over a 650-km range, from the southwestern Minas Gerais to the southeast of Goiás and the Federal District, at the base there is a sequence of shales that gradually rises to the top with a sandy contribution, from quartzphyllites, micaceous quartzite, quarzite and finally to orthoquartzite underpinning the slopes of the mountains and plateaus. The entire sequence of this group shows a lateral and vertical gradation between phyllite and quartzite packages. Internally, each package has the same gradation on a smaller scale, showing the rhythmicity of the entire set.
Barbosa et al. (1970) characterized the Ibiá Formation as a band of calco-schists that occurs along the Quebra-Anzol River, near the city of Ibiá. It is composed of calco-sericite and chlorite schists invariably micro-folded and crenulated, presenting neoformation of beds and quartz cores with calcite always present in non-weathered outcrops (Rio Verde formation). Braun \& Baptista (1978) highlighted the occurrence of this formation around the quartzitic ring of Barreiro alkaline massif (Araxá) and in the interbedded quartzite of Serra de Pirapetinga. According to Ferrari (1989), the Ibiá Formation belongs to the Araxá Group and because it is near the granite-gneissic basement is likely to constitute the basal portion thereof. The Araxá Group is tectonically placed over the Ibiá Formation and covered by the sandstones of the Botucatu Formation, of the Paraná Basin and its units have both sedimentary (schists and quartzite), and magmatic (amphibolites) origin, their structural complexity makes it difficult to separate into formations. This group was metamorphosed in amphibolite facies of 630 Ma age (Seer, 1999) and the São Francisco Basin is represented in the area by the Santa Fe, Areado, Mata da Corda and Urucuia groups that developed during the Cretaceous and in this basin, the phosphates are concentrated in the Mata da Corda Group.

The Alto do Paranaíba Alkaline Province (APAP), located on the NE border of the Paraná Basin, is characterized by magmatic manifestations of the Cretaceous period (Barbosa et al., 1970), during the uplift of an arch that separated the Paraná and São Francisco basins (Campos \& Dardenne, 1977). Kimberlite, carbonatite and kamafugite are the main representatives of this manifestation, while the latter group represents the most significant known spill of this kind in the world, with approximately $23,000 \mathrm{~km}^{2}$ (Gibson et al., 1995). According to the same authors, this province and the surrounding alkaline provinces originated from the rise of the Trindade Mantle Plume, which was also related to the basaltic spill of the Paraná Basin and the APAP has important mineral deposits associated with intrusions, mainly carbonatite (Catalão I and II, Serra Negra, Salitre I and II, Araxá and Tapira) from which phosphate ore, niobium, titanium and rare earth minerals are extracted and phlogopite picrite dykes (Dardenne \& Schobbenhaus, 2003).

\section{RESULTS}

\section{Gamma ray spectrometric}

The gamma ray spectrometric maps were generated for interpretation: Potassium (K), Thorium (eTh), Uranium (eU), Total Count (TC); the ratios, eU/eTh, eU/K and eTh/K; RGB (K:eTh:eU) and CMY (K:eTh:eU) composite images. The image of the total count 
of channel represents a measure of the total radiation present in the energy spectrum of gamma rays, which are contained in the photopeaks and the energies related to $\mathrm{K}$, eU and eTh. The interpretation of the total count of image enabled the definition of a framework with gamma spectrometric domains and structures for the entire area. It was also possible to study the lineaments, which, in general, depict the contact area between the large units (see Fig. 5d), this allows also a joint analysis of discrimination made in order to have an idea of what actually contributes to the formation of gamma spectrometric relief portrayed in this channel and the gamma spectrometric framework defined for the area resulted in three major large areas as follows (Fig. 2b).

The zone 1 domain (Zn1, Figs. 2a and 2b) contains the main metasedimentary phosphate units in the region, located in northeast portion of the area, the gamma spectrometric total count varies from low (blue) to high (magenta). The areas of high gamma ray spectrometric total count represent a wide zone, trending NNW-SSE, varying from high to very high (magenta) (Fig. 2a), the individual channel maps, eTh, $\mathrm{K}$ and eU, show primarily a high concentration of eTh and eU (Figs. 3a and 3c), while potassium presents very low values (Fig. 3b).

The Digital Terrain Model (DTM, Fig. 3d) shows a relief above 1100 meters, with the presence of mountain chains, on the other hand, the northern area is generally along the NE-
SW direction the three elements are present in varying proportions, predominantly thorium. Potassium occurs in relatively high amounts; however, this element is largely of hydrothermal enrichment, the Digital Terrain Model (DTM, Fig. 3d) shows a moderate topography, typically the higher relief features of the area, such as hills and plateaus, tend to concentrate thorium because of its low mobility, on the other hand, potassium and uranium concentrate on the slopes, valleys and riverbeds due to higher mobility.

The zone 2 (Zn2, Figs. 2a and 2b) is defined by the central area, a large band from NW to east, trending mainly NW-SE, it is the pink area in the map (Fig. 2b), which is characterized by medium to low total count, varying from yellow-reddish to greenish. There are some plateaus with high to very high gamma ray spectrometric levels in the center of the area and at the eastern edge, in general, these round bodies contain especially thorium and uranium.

Two circular features (Figs. 3a and 3c) that concentrate large amounts of thorium and uranium can be seen in the center-north of this area (Fig. 2a), potassium occurs as a thin halo surrounding these bodies, indicating a high degree of leaching, on the other hand, the center of the area shows a high concentration of potassium (Fig. 3b). The topography in this area is higher than 1000 meters, at the eastern edge, there is a feature with NE direction

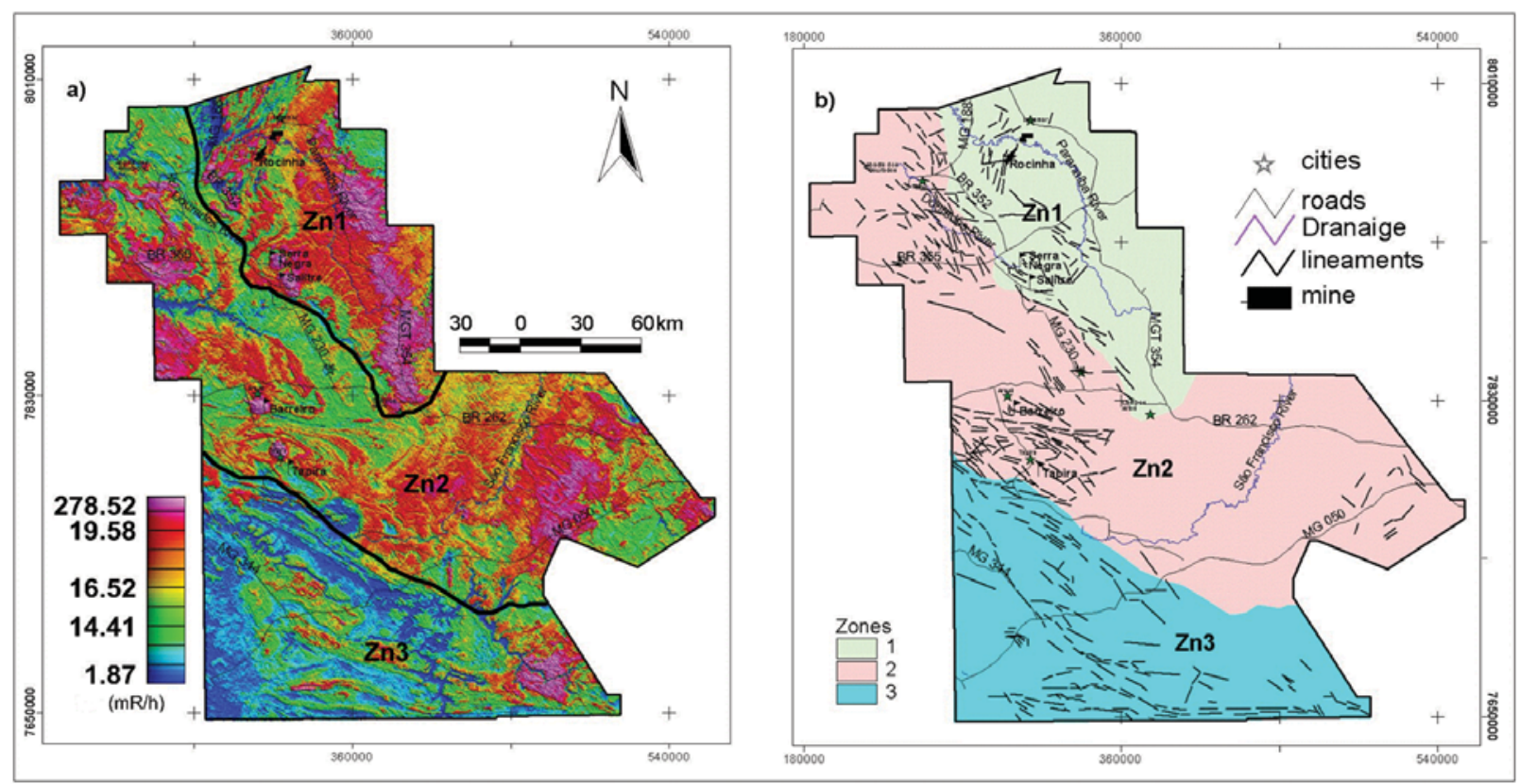

Figure 2 - Total Count Maps (2a) of the Integrated Areas 1 and 7 and the regional gamma spectrometric framework (TC, 2b), divided into three major zones based on their gamma spectrometric characteristics (TC, 2b). It is observed that phosphate areas occur in carbonatites and metasediments, which are concentrated in high gamma ray spectrometric zones 1 and 2 (Zn1 and Zn2). 


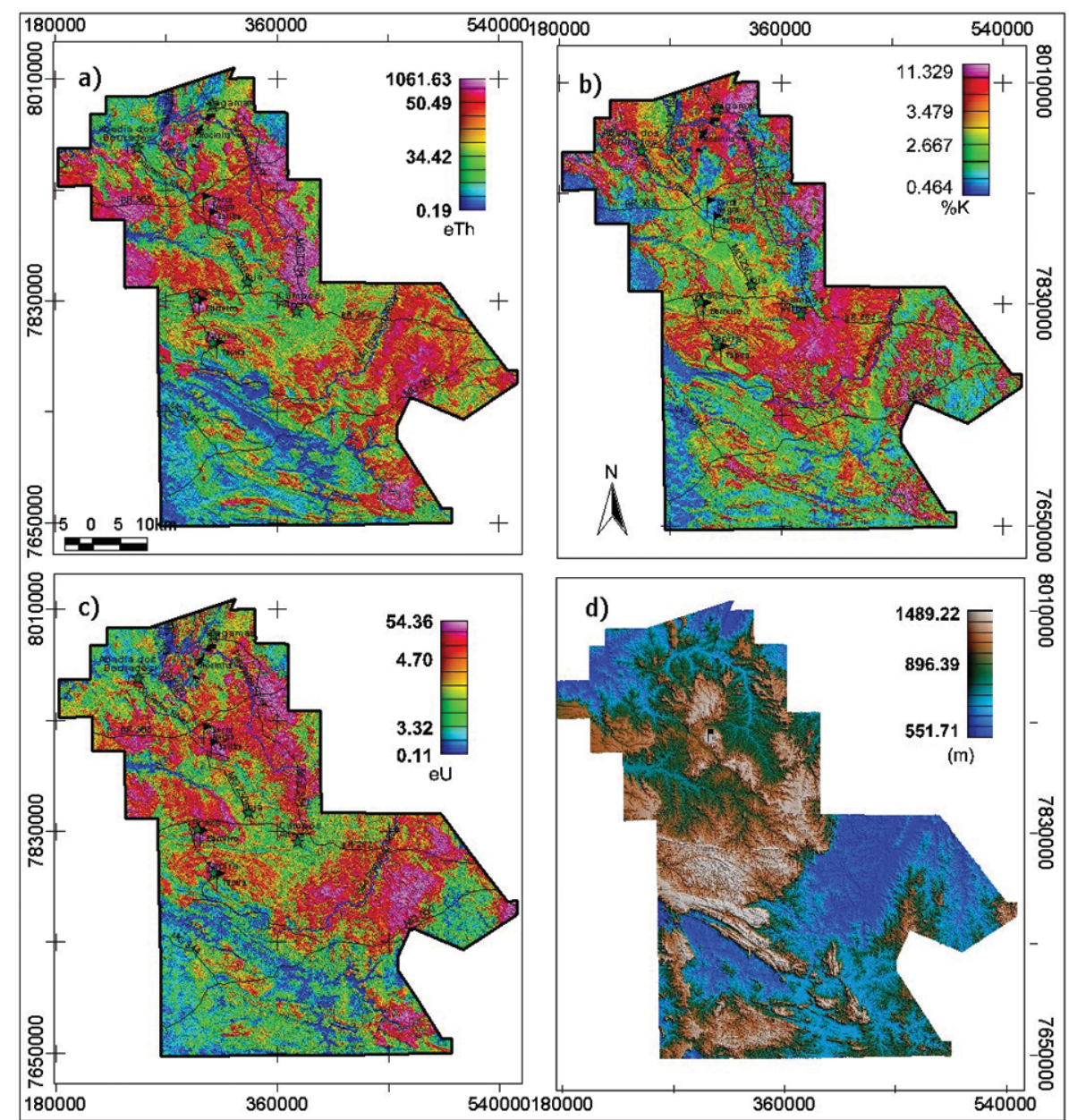

Figure 3 - (a) Thorium (eTh); (b) Potassium (K); (c) Uranium (eU); and (d) Digital Terrain Model (DTM).

that cuts the entire area where no potassium is observed (Fig. 3b) and all carbonatite bodies that host phosphate deposits are within this area.

The zone 3 (Zn3, Figs. 2a and 2b) is represented by the blue color on the map (Fig. 2b), occupies the southern part of the region, its main structures trend NW-SE, varying to E-W toward the southern end of the area, very low gamma spectrometric count, topography ranging between 600 and 800 meters. In this area, there is very low concentration of the three elements $(K$, eTh, eU), higher concentrations of thorium and uranium are found only in a few isolated areas in the south and southeast end (Figs. 3a and 3c). In the east-central portion, the concentration of the three elements varies, potassium concentrates in lower relief and drainage areas, while thorium and uranium are found in higher relief regions (Fig. 3d).

The eU/K (Fig. 4b) image shows good discrimination of rock types, including internal composition variations of some units and the higher topography areas, such as plateaus, are shown in this picture. Comparing this ratio with the CMY image (Fig. 5b), one can see a very similar correlation with the units found in this composition, the eTh/K ratio (Fig. 4c) allowed interpreting the distribution of potassium related to possible alteration zones. The extreme east and northeast and far western areas are characterized by high values of this ratio, this ratio displays lower values in areas where potassium is concentrated, which are mostly associated with lower topography regions like valleys and drainage areas, the areas with high eTh/K ratios are associated with plateaus in the entire region. Moderate values are observed in the far south while moderate to low (green) and low (blue) concentrations occur over the remaining area.

Two types of ternary images, RGB and CMY compositions (Figs. 5a and 5b) were prepared, in both cases, the three gamma ray spectrometric channels, $\mathrm{K}$, eU and eTh were assigned to a primary color channel. In resulting product, each pixel reproduces 


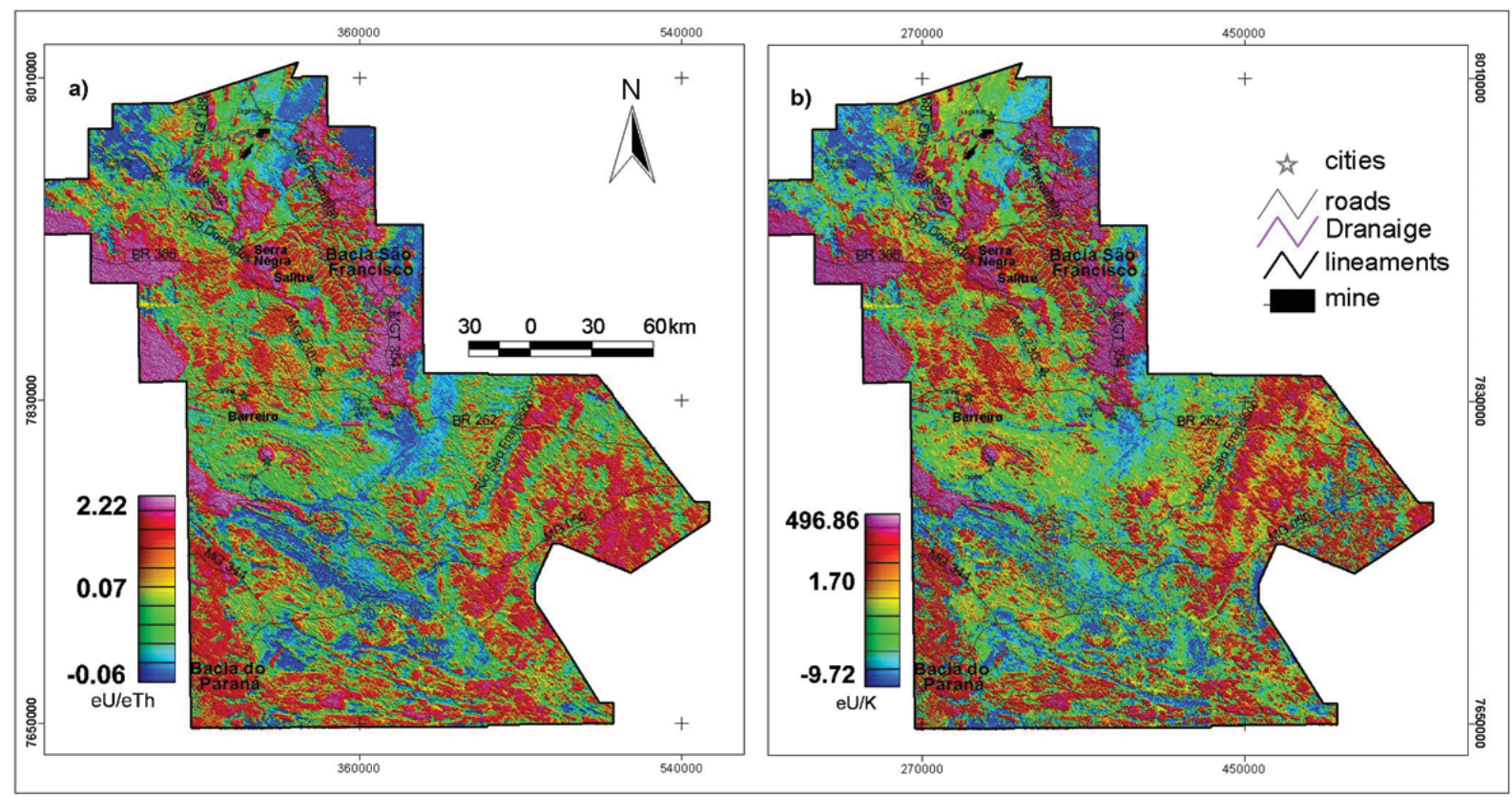

Figure 4 - Maps of (a) eTh/K and (b) eU/K ratios.

the color that reflects the relative intensity values of gamma radiation between the three components channels, in RGB compositions, the amounts of the primary colors, red, green and blue, are added so that the most saturated colors (whitish) of ternary image reflect higher intensities in the three forming elements. The opposite occurs with less saturated portions (dark). For CMY composition, the figures for the primary colors cyan, magenta and yellow, are subtracted so that the most saturated regions are distinguished by low expression gamma spectrometric on all channels (more saturated colors), while lower saturation brand more servings gamma radiation in significant for all three channels.

In the RGB composite, red was attributed to potassium; green, to thorium; and, blue to uranium. Furthermore, in the CMY composite, cyan corresponds to potassium, magenta to thorium, and yellow to uranium. These images were used to separate the gamma spectrometric units in the study site, the RGB composition is more efficient to reveal variations when the concentrations are high, while the CMY composite performs better when concentrations are lower. Ternary images proved to be excellent gamma ray spectrometric discriminators due to the variety of colors that delineate the units very effectively (Fig. $5 c$ ) and these images were overlaid on a TDM because such superimposition results in better definition of the gamma spectrometric areas and more resources to separate the units that map different soil types.

The RGB and CMY images associated with the DTM were used to assess the behavior of radioelements with respect to terrain topography, the interpretation consisted of visual analysis of the images and combining the three elements in one map to differentiate internal variations of major domains defined from the total count map. The regional map (Fig. 2b) yielded a new detailed classification (Fig. 5c) where it became possible to identify new gamma spectrometric units, in addition, the regional map was integrated with the lineaments map of the area (Fig. $5 d$ ), it is noted that some units appear in more than one zone.

Zone 1 (Zn1, Fig. 2b) was subdivided into six (06) different domains using the gamma ray espectrometric maps, adding geological information to the area which is not mapped in Geological map of Alto do Paranaíba Province (Bizzi et al., 2003) in Figure 1. The domain 2 (U2) is an important part of this area because it contains a large amount of uranium in its south-central portion (U2A, Fig. 5c), moreover, Zone 2 (Zn2) contains the highest variety of radio-elements and behaviors that were quite different from the other domains, as seen in Figure $5 \mathrm{c}$ and it was divided into twelve (12) domains. Zone 3 (Zn3) was divided into six (06) domains.

Lineaments were interpreted from all gamma ray spectrometric images on the 1:100,000 and 1:50,000 scales (Fig. 5d), the majority represents the geological contacts between domains, the Figure $5 d$ shows the predominance of NW-SE structures, along the central and southern extension of the area, trending from $10^{\circ}$ to $30^{\circ} \mathrm{Az}$ and represents the main event in the area. A second set of structures, in the approximate N-S direction, can be 




Figure 5 - Maps of (a) RGB composite for (K-eTh-eU); (b) CMY composite for (K-eTh-eU); (c) gamma ray spectrometric domains; and (d) lineaments obtained from gamma RGB and CMY composite.

seen especially in the east-central and northeastern portions and a third set of linear lineaments trend NE-SW.

\section{Magnetometry}

Several techniques were applied to the magnetic data in order to enhance the structures and facilitate the differentiation of magnetic signatures to better understand the different units domains and the following discussion shows the analysis and interpretation of the results of such data. This step served to define linea- ments, anomalies of large wavelengths, the magnetic fields, relationship with the structural framework, geological correlation, identification of anomalous zones and the definition of phosphate mineralization in the region, the main transformations included the anomalous magnetic field (AMF); vertical derivative (VD); Analytic Signal Amplitude (ASA); and, Analytic Signal Inclination (ASI). The analysis of this information delineated the structures and important magnetic features and the objective of interpreting the anomalous magnetic field (Fig. 6a) is to determine the patterns capable of individualizing the units with distinct behavior 


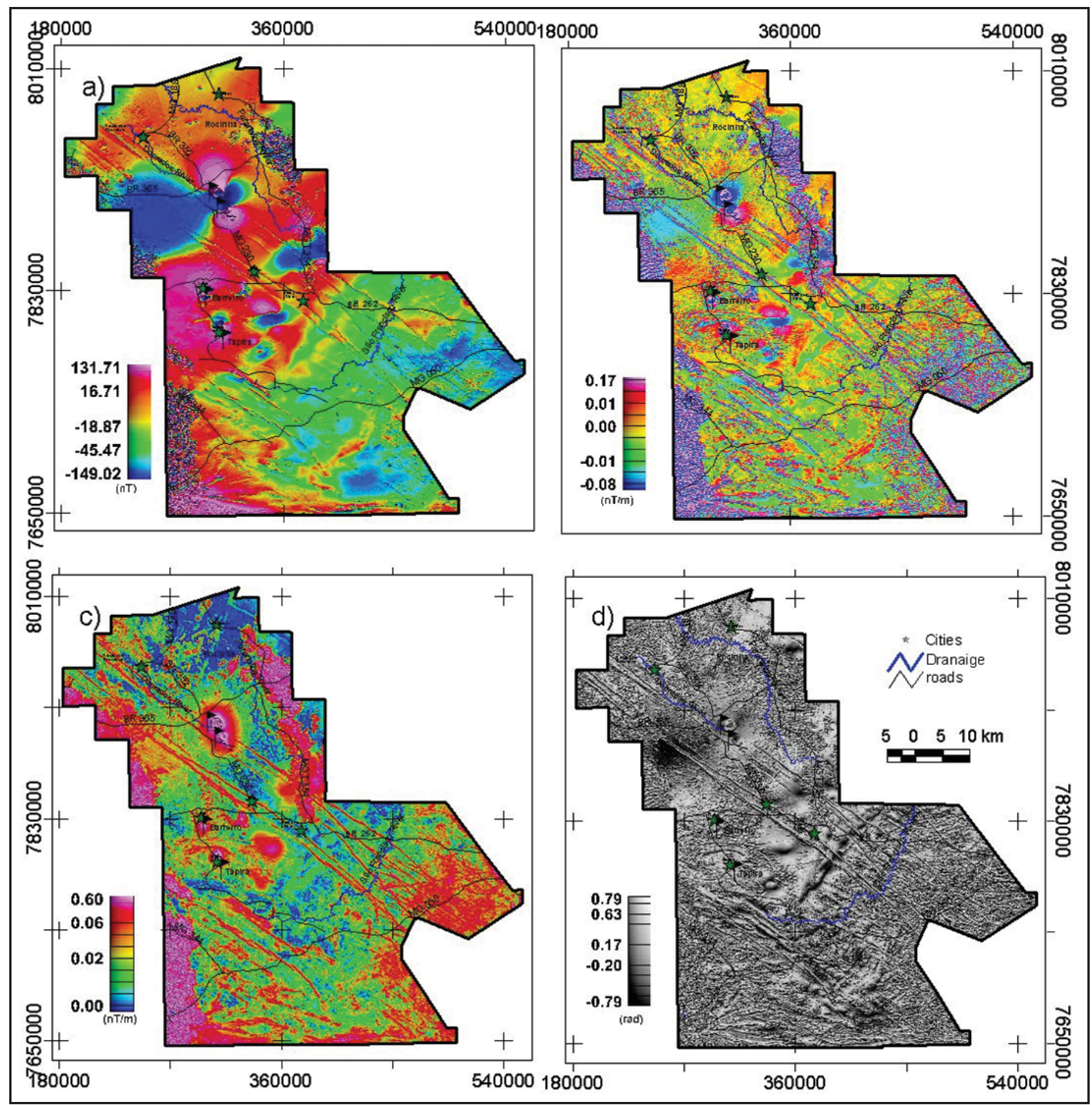

Figure 6 - Maps of (a) anomalous magnetic field (AMF); (b) first vertical derivative (VD); (c) Analytic Signal Amplitude (ASA); and, (d) Analytic Signal Inclination (ASI), showing anomalies of short and medium wavelength trending NW-SE, mainly AMF (6a) and ASA (6c).

and signature patterns that can translate important features (linear or nonlinear) and to correlate them with mineralizations.

Overall, the analysis shows alternating bands with low values (blue) and top (red) wavelengths, NW-SE trending with quite irregular behavior (Fig. 6a), where low values (blue-greenish) wavelengths are observed from center to east and from southeast to south, on the other hand, high values wavelengths are observed in parts of central and north-central, as well as in the western area (red to magenta, Fig. 6a), both domains display the general NW-SE trend and quite irregular behavior.

The northern portion, moderate values (red-yellow) predominate while the relief is relatively monotonous, on the other hand, the center of the area displays different features, in this region, dipolar anomalies range between $241 \mathrm{nT}$ and $2900 \mathrm{nT}$, several dipolar anomalies are observed throughout this region, with smaller dimensions wherein it is noteworthy also a number of anomalous magnetic signatures with preferential NW-SE directions. This region is cut by several features that cross the entire region from NW to SE, a signature that resembles rocks in brittle deformation and this area is cut by NW-SE trending linear features (Fig. 6a).

In the southern part, the magnetic relief shows two distinct behaviors, the further south/southeast is marked by signatures with negative values (-149.02), showing WSW-ENE oriented 
valleys (shades vary from blue to green), on the other hand, in the south/southwest edge, the relief is formed by a series of strongly marked peaks that stand out from the whole area and these features behave as scars well marked by valleys and ridges of high wavelengths (dark red) with $200 \mathrm{nT}$ intensity, and with shallow characteristic (Fig. 6a).

The comparison between gamma spectrometric and magnetic data (Fig. 7a) shows that some features are common to both geophysical data and the bodies that host phosphate mineralization are the areas with the highest magnetization, and it becomes evident that they are the magnetization sources, as seen in the images of VD and ASA (Figs. 6b and 6c, respectively). The interpretation of magnetic lineaments (Fig. 7b) allowed observing different magnetic and structural events, those that could be translated into signatures due to deformations that affected the region and rocks are marked and The main NW-SE system, located in the central region, cuts others less abundant, chiefly in the NE-SW direction (Fig. 7).

It can be said that these three systems dominate the orientations of linear features observed: one with NW-SE orientation (D1) that seems to pair with the second in the NE-SW direction (D2) and a third, in the E-W direction (D3) that is well represented and appears to be the last event of the three (Figs. 6 and 7). The linear features in the central area (D2) probably represent shear zones, is cut by NW-SE lineaments, and is marked by features with approximate $\mathrm{N} 40^{\circ} \mathrm{E}$ direction, configuring, probably a system of sinistral strike-slip fault movement since some D2 lineaments are displaced by D1, this can be seen in the large lineament that crosses the area in the central portion, as well as other regions.

\section{DISCUSSION AND CONCLUSIONS}

The processing, integration and analysis of geophysical data yielded products that are suitable to differentiate rock types, continuity of lineaments and geophysical domains with distinct characteristics and these differences are based on the responses due to the contrasting physical properties, the characteristics of the research method and the enhancements obtained with processing.

The gamma ray spectrometric data contributed the most to separate the bodies that house phosphates in metasedimentary rocks, even the responses of these rock types to geophysical data, the best images to delineate the rocks that host sedimentary phosphate deposits are eU (Fig. 3c), U/Th (Fig. 4c), RGB and CMY (Figs. 5a and 5b). On the other hand, potassium forms a thin halo around these bodies while some portion of this element has been probably leached into the basement in the lower parts of the area (Fig. 3b).

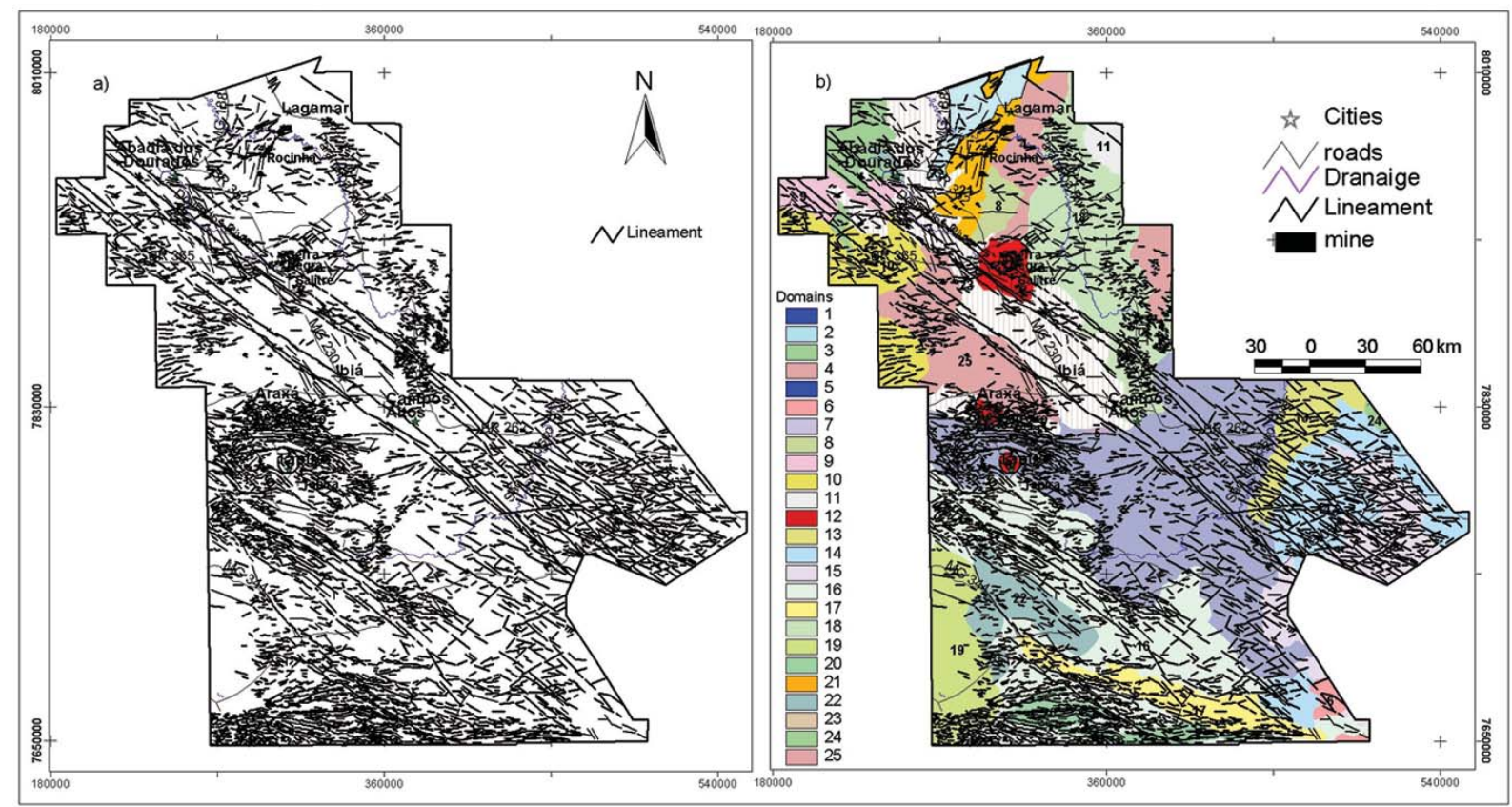

Figure 7 - Maps of (7a) magnetic structures interpreted from the magnetic images; (7b) magnetic structures interpreted from superimposing the gamma spectrometric and magnetic maps; background is gamma ray spectrometric domains (Fig. 5c). 
Based on the geophysical data, it is observed that the phosphate hosting bodies in the metasedimentary rocks are characterized as elongated, NE-SW trending, approximately $30 \mathrm{~km}$ long and $2 \mathrm{~km}$ wide, with high values of eU, eU/eTh (Fig. 8). Magnetometry shows that these sedimentary bodies have predominantly average values $(0.01-0.10)$ and a relatively monotonous relief. The prevailing NE-SW trending structures are slightly displaced to the east, with the exception of the areas with circular bodies, in these areas, the lineaments display E-W trend. Small bodies with geophysical characteristics very similar to those that host the phosphates can be identified west of Rocinha. These data associated with geological data mapped for the region can be associated with the sedimentary units A and B of Vazante Group and represent the Lagamar and Rocinha facies, respectively, while mineralization is observed in the whole body (Fig. 8), several round bodies, which are very common in the area, are identified as kimberlite/kamafugites diamond carriers occurring in this region.

For the phosphate hosted in carbonatites, the geophysical shows anomalies associated, the AMF image and its derivatives, vertical gradient (VD, Fig. 6b), amplitude (ASA, Fig. 6c) and phase of the Analytic Signal Inclination (ASI, Fig. 6d) were very useful to characterize the lineaments, domains and magnetic sources. On the other hand, in gamma spectrometry, the best responses were obtained from the eTh (Fig. 3a), eU (Fig. 3c), RGB and CMY (Figs. $5 \mathrm{a}$ and $5 \mathrm{~b}$ ) maps, potassium occurs as a thin halo around bodies that host phosphate (Fig. 3b) was totally leached into the basement rocks. In general, round carbonatite bodies are housed on the edges of lineaments, but presenting stretches and breaks at the ends probably due to structural movements, they have a high concentration of eTh and eU and concentrated potassium as

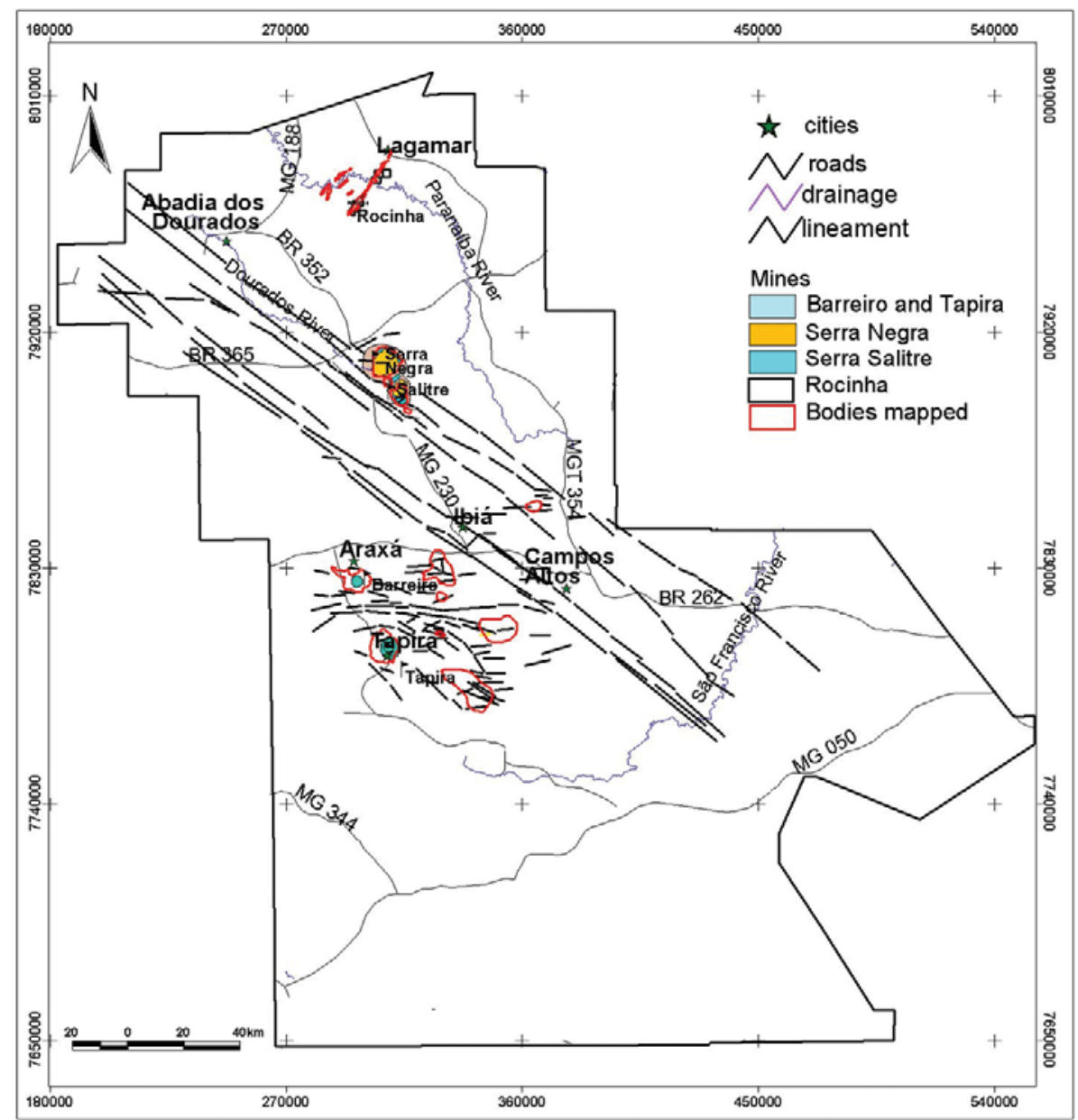

Figure 8 - Map showing the integration of chosen targets for follow up and the main NW-SE and E-W trending lineaments that control this mineralization are included in this map. The areas in red have been identified and mapped by the geophysics as carbonatite bodies. Some regions were identified only by magnetometry. It is observed that the areas mapped to the carbonatites of Araxá (Barreiro) and Tapira are larger than the currently known. 
halos around these bodies. Generally, in the regions with phosphate concentration, potassium is more concentrated and phosphate mineralization occurs at the outer edges of these bodies.

The Analytic Signal Inclination (ASI) determined the lineaments with NW-SE, E-W and NE-SW directions, according to the structural framework known in the literature, the NW-SE lineaments are assigned to an older event, probably from the Early Cretaceous, marked by the opening of the rift process in the region and intensified in the Late Cretaceous. E-W lineaments are assigned to a later cycle or even reactivated at this stage, but it is observed that the NE-SW structures occurring in east-central area are cut by NW-SE structures, which were interpreted as the first event in the area.

Figure 8 shows the areas with known mineralization and phosphate exploitation process, and also the bodies identified through such geophysical and geological contrasts showing subsurface bodies that may be promising areas for future phosphate abstractions in the region. Between the cities of Tapira and Campos Altos, a body somewhat similar to the bodies of Serra Negra is observed and and their characteristics can be identified by the potassium, where halos surround it and magnetometry shows the characteristic aspects in other carbonatite bodies (Fig. 8). There is another body to the south/east of Tapira, which presents the geophysical characteristics of carbonatite, only identified with the magnetometric data. To the N/NE of Campos Altos, another characteristics signature is observed, indicating the occurrence of carbonatites, which it might be covered up by the Bambuí rocks (Fig. 8). Geophysical analysis shows several carbonatite bodies in the area, some are exploited while other are still not identified and are observed only in magnetometry (Fig. 8).

They are located at the faults borders, do not exhibit regular patterns, display varying shapes, some are elongated, others rounded and even flattened. The internal patterns are different, resulting from the influences of mineralogical variations and tropical weathering that the phosphate mineralization undergoes. The carbonatite complex of Serra Negra, Salitre and Tapira belong to bebedouritic series, which are rocks produced by fractional crystallization of ultrapotassic silicate magma (picrite phlogopite) and modal variations in the amounts of olivine, clinopyroxene, apatite, magnetite and phlogopite, on the other hand, the Barreiro complex (Araxá) belongs to phosphoritic series derived from phosphatic magmas with modal variations in apatite, magnetite and olivine and this differentiation is recorded by geophysics.

The integrated geological-geophysical correlation shows that magnetic fields have a direct correspondence with the geology of carbonatite due to the high content of magnetic minerals in its composition and according to the literature the carbonatite complex of Alto do Paranaíba belongs to the carbonatite-kamafugite association. Petrography states that it belongs to three different series of differentiation (bebedouritic, phosphoritic and carbonatitic) whose evolution is closely related to processes such as fractional crystallization and/or immiscible liquids, from primitive magmas of kamafugitic affinity.

Alkali metasomatism of varying intensity transformed the primary ultramafic rocks into phlogopitites in varying degree the Neoproterozoic host rocks (Gibson et al., 1995; Brod et al., 2000), the strong anomalies that cut across the central region have been interpreted as the Alto do Paranaíba structure (Campos \& Dardenne, 1997). According to these authors, this arc divides the Paraná and São Francisco basins whose uplift began in the Early Cretaceous, intensified in the Late Cretaceous, thus influencing the tectonic-stratigraphic evolution of the two basins. Its strong magnetization is related to the dyke swarms.

\section{ACKNOWLEDGEMENTS}

The authors are thankful to CNPq for the financial support, CODEMIG for providing the data, and Universidade de Brasília for allowing the use the Laboratory of Applied Geophysics (LGA). ESRI for providing the ArcGIS 10 software, under contract no. 2011 MKL8733 and IMAGEM for the support to the software and for making the IG-UNB and ESRI contract work.

\section{REFERENCES}

ALMEIDA, FFM. 1976. 0 Cráton do São Francisco e suas faixas marginais de dobramentos. In: Congresso Brasileiro de Geologia, 29., Resumos Expandidos, Ouro Preto, Minas Gerais, Brazil: SBG, 241-215.

BARBOSA 0, BRAUN OPG, DYER CR \& CUNHA CABR. 1970. Geologia da região do Triângulo Mineiro. Rio de Janeiro, DNPM/DFPM, 140 pp. (Boletim 136).

BIONDI JC. 2003. Processos metalogenéticos e depósitos minerais brasileiros. Oficina de Textos: São Paulo, Brazil, 528 pp.

BIZZI LA, SCHOBBENHAUS C, VIDOTTI RM \& GONÇALVES JH. 2003. Geologia, Tectônica e Recursos Minerais do Brasil. Texto, Mapas \& SIG. Serviço Geológico do Brasil - CPRM. 642 pp.

BRAUN OPG \& BAPTISTA MB. 1978. Considerações sobre a geologia pré-cambriana da região sudestee parte da região centro-oeste do Brasil. Salvador. SBG/Núcleo Bahia. Boletim Especial, 3: 225-231.

BROD JA, GIBSON SA, THOMPSON RN, JUNQUEIRA-BROD TC, SEER HJ, MORAES LC \& BOAVENTURA GR. 2000. The KamafugiteCarbonatite Association in the Alto Paranaíba Igneous Province (APIP) Southeastern Brazil. Rev. Bras. Geociências, 30(3): 408-412. 
CAMPOS JEG \& DARDENNE MA. 1997. Origin and tectonic evolution of the basin Sanfranciscana[in Portuguese]. Rev. Bras. Geociências, 27(3): 283-294.

COSTA LAM, ANGEIRAS AG, VALENÇA JG \& STEVENAZZI V. 1970. Novos conceitos sobre o Grupo Bambuí e sua divisão em tectonogrupos. Rio de Janeiro. Bol. Geoc. Inst. Geociências, 5: 3-34.

DARDENNE MA. 1978. Zonação tectônica na borda ocidental do Cráton São Francisco. In: Congresso Brasileiro de Geologia, 30., Proceedings... Recife, Brazil: SBG, I: 299-308.

DARDENNE MA. 2000. The Brasillia Fold Belt. In: CORDANI UG, MILANI EJ, THOMAZ FILHO A \& Campos DA (Eds.). Tectonic Evolution of South America. 31st International Geological Congress, pp. 231-263.

DARDENNE MA \& SCHOBBENHAUS C. 2003. Depósitos Minerais no Tempo Geológico e Épocas Metalogenéticas. In: BIZZI LA, SCHOBBENHAUS C, VIDOTTI RM \& GONÇALVES JH. (Eds). Geologia, Tectônica e Recursos Minerais do Brasil. Texto, Mapas \& SIG. Serviço Geológico do Brasil-CPRM. pp. 365-448.

DARDENNE MA, FREITAS-SILVA FH, DOS SANTOS GM \& SOUZA JFC. 1997. Depósitos de Fosfato de Rocinha e Lagamar, Minas Gerais. In: SCHOBBENHAUS C, QUEIROZ ET \& COELHO CES (Eds.). Principais depósitos minerais do Brasil - Rochas e minerais industriais, 4v (v. 4c). Brasília, Brazil: DNPM, pp. 113-122.

DNPM - Departamento Nacional de Produção Mineral. 2008. Sumário Mineral - Edições 1996-2008 - Texto Fertilizantes Fosfatados Naturais.

FERNANDES FRC, ADÃO B. DA LUZ \& CASTILHOS ZC. 2010. Agrominerais para o Brasil. Centro de Tecnologia Mineral. Rio de Janeiro: CETEM/MCT.
FERRARI PG. 1989. A Formação Ibiá e sua pertinência ao Grupo Araxá. In: Simp. Geol. Minas Gerais, 5., Anais, SBG Belo Horizonte, Brazil, pp. 257-261.

FONSECA MA \& DARDENNE MA. 1996. Arcabouço estrutural e evolução cinemática da faixa Brasília em seu segmento setentrional. In: Congresso Brasileiro de Geologia, 34., Salvador. Resumos Expandidos, 6: $98-100$.

FUCK RA. 1994. A Faixa Brasília e a Compartimentação Tectônica da Província Tocantins. In: Simpósio de Geologia do Centro-0este, 4., Proceedings... Brasília, Brazil: SBG, 1: 184-187.

GIBSON SA, THOMPSON RN, LEONARDOS OH, DICK AP \& MITCHELL JG. 1995. The Late Cretaceous impact of the Trindade Mantle Plume evidence from large-volume, mafic, potassic magmatism in SE Brazil. J. Petrol., 36: 189-229.

SÁNCHEZ E, YAGÜE C \& GAERTNER MA. 2007. Planetary boundary layer energetics simulated from a regional climate model over Europe for present climate and climate change conditions. Geophysical Research Letters, 34: 1-6.

SANT'ANNA LG, RICCOMINI C \& VALARELLI JV. 1999. Ocorrência de fosfato de terras raras na Formação Resende, Paleógeno do Rift Continental do Sudeste do Brasil. Revista do Instituto Geológico, 20(1/2): $37-47$.

SEER HJ. 1999. Evolução Tectônica dos Grupos Araxá, Ibiá e Canastra na Sinforma de Araxá, Minas Gerais. Doctorate thesis, Instituto de Geociências, Universidade de Brasília, Brasília, Brazil, 267 pp.

Recebido em 2 abril, 2014 / Aceito em 13 julho, 2014

Received on April 2, 2014 / Accepted on July 13, 2014

\section{NOTES ABOUT THE AUTHORS}

Leila Márcia Mendes Carvalho. Graduated in Geology at Universidade Federal do Pará (1996), specialized in Geology at Universidade Federal do Pará (1997). M.Sc., in Geology at Universidade Federal de Ouro Preto (1999), Ph.D. in Geology and Applied Geophysics at Universidade de Brasília (2006) and Post-Ph.D. in Applied Geophysics at Universidade de Brasília (2014). Has experience in Geophysics with emphasis on gamma spectrometry, magnetometry and gravimetry methods applied geological mapping and mineral prospecting.

Augusto César Bittencourt Pires. Graduated in Geology at Universidade Federal do Rio de Janeiro (1968). Ph.D. in Geophysics from Colorado School of Mines (1975). Was head of the Department of Geophysics of ENCAL SA; Head of the Department of Geophysics of the National Observatory. In CNPq was Supervisor, Coordinator and Superintendent of Exact and Earth Sciences and Director. Was Program Director of CAPES and Coordinator of Policy and Plans of the MCT. Was selected as Senate Legislative Consultant. Specialized in the application of geophysical methods in geological mapping, mineral exploration and the environmental analysis. Retired Professor of Geosciences Institute, is currently Senior Researcher at Universidade de Brasília.

Roberta Mary Vidotti. Associate Professor at the Instituto de Geociências of Universidade de Brasília. Graduated in Geology at Universidade Federal Rural do Rio de Janeiro (1987), specialized in Geology and Marine Geophysics at Universidade Federal Fluminense (1987). M.Sc. in Geophysics from Observatório Nacional (1992) and Ph.D. in Geophysics at the University of Leeds (1997). Has experience in Applied Geophysics, with emphasis on gravity, magnetic and gamma ray spectrometry methods applied to regional geology, geotectonic, sedimentary basins and mineral prospecting. 